\title{
The Images of Nature in Wordsworth's and Al- Bohtory's Poetry: A Comparative Study of Selected Poems
}

\author{
Mohammed A. Al Matarneh \\ Department of English Language and Literature, Tafila Technical University, Tafila, Jordan \\ Emad A. Abuhammam \\ The Ministry of Education, Jordan
}

\begin{abstract}
This study tackles the representation of nature in poetry, mainly in Wordsworth's and Al-Bohtory's poems. This study is based on the theoretical and analytical approaches of Russian Formalism that focuses on studying the linguistic aspects of the literary texts. Russian Formalism studies texts through "structures, imagery, syntax, rhyme scheme, paradox, personification and other literary devices" (Bressler, 2011, p. 49). The significance of the study lies in its purpose to introduce a comparison between two different poets whose cultural backgrounds, languages, traditions and societies are different. Wordsworth sees nature as the perfect place for tranquility and pleasure. He emphasizes that man and nature as basically adapted to each other, and the mind of man as the machine of depicting nature. Wordsworth states that this pleasure comes from the human's interaction with nature in its fascinating images of Spring, flowers, clouds, horses, rivers, castles, seas, gardens, and animals generally. Al-Bohtory also presents nature as a place of pleasure and peace; he accentuates the profound relationship between nature and man, and how nature is admired by humans in its beautiful views. He explains that the beautiful images of nature affect the human's mind and soul. Al-Bohtory portrays most of his poems in marvelous images of nature, such as Spring, horses, clouds, rivers, animals, castles, seas, and flowers. These two poets seek to glorify nature and its magnificent impact on humans' life and pleasure.
\end{abstract}

Index Terms-poetry, nature, comparative study, Russian formalism, wordsworth, Al-Bohtory

\section{INTRODUCTION}

This study presents a comparative study between William Wordsworth, an English poet and Al-Waleed Al-Bohtory, an Arabic classical poet during the Abbasid era. Al-Bohtory is a classical poet in Arabic literature. He is Abu Obada- Al Waleed Bin Obaid-Bin Yahia- Al-Bohtory -Al Tai'e. He was born in the northern region of Syria in Manbaj area in (821CE), and lived in the Arabian Badia among his siblings and relatives and died in (897CE). He wrote about many Arabic classic writers and poets at that time, such as Abu- Al Abbas Al Mubarad. Al-Bohtory "kept in touch with AbuTammam, who was his spark of inspiration" (Al-Basri, 1944, P. 13). On the other hand, William Wordsworth was born at Cockermouth Cumberland in the Lake Country of England, on April 7, 1770. He lived his boyhood there. He is one of the first great modern poets of England and Europe. Mark Doren (1951) states that "He still speaks for a special world, our world, that has great need of him, and to say this is to define the modern age" (p. 9). The study compares the poetic lines of describing nature of Al-Bohtory in the Arab-Muslim tradition and that of William Wordsworth in the English literary tradition. This parallelism involves the style of composition, poetic images, some poetic symbols, metaphors and similes. Most important, though, is the parallelism in the major parallel situations and modifications each of them appears to be undergone to its original sources.

This study provides a comparison of portrayed poetic images by Wordsworth and Al-Bohtory in presenting nature images, symbols and figurative language through their poems. All of Al-Bohtory's poems shown in the study are based on our translation. Moreover, Al-Bohtory's poems are quoted basically from Al- Hasan Al-Basry's book "The Parallelism between Abu-Tammam and Al-Bohtory", edited and published in 1944, and Saleh Al-Yathi's book "AlBohtory Among his Critics", published in 1982. Wordsworth's poems are basically quoted from Mark Doren's book "The Works of William Wordsworth", published in 1951. While this study provides a comparison between two poets whose languages, societies, cultures, and eras are different.

\section{QUESTIONS OF THE STUDY}

1- How do Wordsworth and Al-Bohtory treat nature in the selected poems?

2- To what extent does nature affect human's mind and pleasure as portrayed in Wordsworth's and Al-Bothory's selected poems?

3- What are the main natural subjects used in the selected poems? 
4- What does each natural subject symbolize as shown in the selected poems?

5- What are the similar themes and linguistic aspects presented in the selected poems?

\section{ReSEARCH Methodology}

This study is based on the analytical and comparative methods. Wordsworth's and Al-Bohtory's selected poems will be compared at different levels in order to assess and analyze the ideas and themes, in addition to figuring out the importance of their poetry. Furthermore, the study also focuses on how each poet presents and acts with nature, and how it is portrayed through the poems.

Comparative technique will be applied to present the images by contrasting them against one another and showing the importance each poem involves. The study considers some theoretical and practical sides of the Russian Formalism that contains studying some linguistic sides, such as "metaphors, similes, rhyme schemes, paradox, personification...etc" (Bresseler, 2011, p. 42). The two poets present not only poetry, but all aspects of memory and Nature have had until now. Poetry gives the typical platform for a convenient approach to Nature. Poetry in this case, has more than literary clues and intentions. The samples of the study are Wordsworth's "Lines Written in Early Spring", "Lines Composed a Few Miles above Tintern Abbey, On Revisiting the Banks of the Wye during a Tour. July 13, 1798","The Horse", "Elegiac Stanzas Suggested by a Picture of Peele Castle in a Storm, Painted by Sir George Beaumont", " I Wandered Lonely As A Cloud”, “A Spring Morning” and "The World is Too Much with us" poems. Also, the study examines the depiction of nature in Al-Bohtory's "وصف الربيع"(A Description of Spring), "الخيل" (The Horse), "وصف قصر المنوكل"(A Description of Al-Mutawakel’s Castle), "العيش في ليل دارياء"(Living in Darya’s Night),

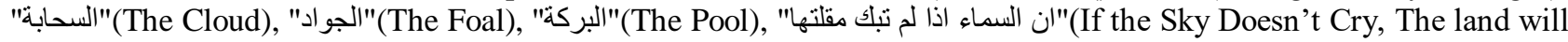
not laugh with greenness), and "المنو كلية"(Al-Mutawakiliah) poems.

\section{DisCUSSION AND ANALYSIS}

The investigation of linguistic parallelism will start with the thematic and portrayed images. William Wordsworth portrays the image of nature and uses spring in most of his poems. For example, in "Lines Written in Early Spring", Wordsworth presents his situation as he sits in a small woodland enjoying spring and nature, while he is in the grove. He presents the whole poem in a regular rhyme scheme (abab) in iambic pentameter for each stanza. The persona enjoys the scene while he is surrounded by "blended notes", this setting inspires a gloomy mood. The persona begins to have dark thoughts, but his mood is pleasant as spring, and nature helps him to stay happy:

I heard a thousand blended notes,

While in a grove I sate reclined,

In that sweet mood when pleasant thoughts

Bring sad thoughts to the mind

[....]

To her fair works did Nature link

The human soul that through me ran;

And much it grieved my heart to think

What man has made of man

(Doren, 1951, P. 78)

In the above stanzas, the speaker personifies nature as a woman "To her fair works did Nature link" explaining that it fairly can connect the human soul to nature "nature link" that affects his mood. Thus, the persona follows another personification as "The birds around me hopped and played" showing that pleasure and happy mood are prompted by the birdsong, where one can view bird's acting happily, admiring the woodland in spring. The phrase "hopped and played" is personification to emphasize and present an image of pleasant man with spring. So, the reason of the bird's happiness is spring as the persona is pleasant for listening to the bird. Wordsworth, however, may take an opportunity to claim that nature is connected to humanity through the perception of the soul; nature's soul is not away from humanity and life, despite the fact that it is ignored by other people worldwide. In short, it is man's natural shelter to be closer to nature. The persona concludes the stanza by a question "What man has made of man?", this refers to his relations with other men in the world of ruthlessness and harshness. Wordsworth also presents some natural elements, which can be seen beautifully in spring in "Lines Written in Early Spring" poem as:

Through primrose tufts, in that green bower,

The periwinkle trailed its wreaths;

And 'tis my faith that every flower

Enjoys the air it breaths

The persona likes the flowers, primrose, the blueness of the periwinkle, and the green color of the woodland place where he sits, while those birds hope and play around him. The persona mentions "green bower" to refer to the simplicity and happiness of nature even the periwinkle can spread out and grow happily. Wordsworth sees that nature is the work of God. So, he concludes by reasserting his lament about what "man has made of man" as being away from 
humans and the material world. Thus, the world of nature is presented as pleasurable and cooperated, Wordsworth comments on this poem. He mentions that:

While I was sitting by the side of the brook that runs

Down from the comb, in which stands the village of Alford, through the

Grounds of Alfoxden. It was a chosen resort of mine. The brook fell down

a sloping rock so as to make a waterfall considerable for that country, and, across the pool below had fallen a tree, an ash if I rightly remember, from which rose perpendicularly boughs in search of light intercepted by the deep shade above. (Wordsworth, 1801, P. 331)

Based on this quotation, he concludes that the motive of composing this poem is the beautiful natural subjects that affect him. The beautiful brook that runs down with the magnificent image of Alford where he breaths the beauty of nature leads him to be happy away from being with the others. The quotation is an explanation of the setting that he describes in the whole poem. In the last part of the poem, the persona looks closely at the bright and joyful plants, birds, and other subjects of nature wondering if they are pleased or not in the same poem:

The birds around me hopped and played,

Their thoughts I cannot measure:-

But the least motion which they made

It seemed a thrill of pleasure

Wordsworth refers to the happy birds where he sits and looks at the beauty of nature as the speaker himself "reclined" in a sweet mood. The persona in the final line of the poem repeats his question "What man has made of man?". This shows the superiority of nature to affect the human's mind, especially in spring where all people feel peaceful, enjoyed, happy and calm. The whole metaphor of the poem emphasizes that man's internal emotions are like nature's instinctual aspects. The human feels happiness and joy just from staying alive between the natural beautiful scenes; whereas the speaker laments in the final line man's inability to let this pleasure lie.

Al-Bohtory offers a similar content. Nature is well- depicted by him; he presents in his poem "A Description of Spring". The same image of spring with pleasant depiction of man. Al-Bohtory depicts the image of spring as the source of happiness. The personification "and for the beauty it would speak and laugh" can lead to the conclusion that spring is like the pleasant man who can speak and laugh, because of the beautiful scenes of spring as:

The free proud Spring had gladly come

And for the beauty it would even speak

And Nowruz warned in the intensive darkness

Beautiful flowers that had been sleeping yesterday

The cold dew covered and herniated the flowers as

Telling them secretive words that were hidden yesterday

And from the trees Spring dressed up itself

As making an ornamented adornment

It came to show the eyes pleasure

Which was firstly forbidden to see

And the breeze became calm then I thought

It brought the breaths of the beloved gladly [Our Translation]

(Al-Yathi, 1982, P. 92)

The persona moves to the flowers, he says "flowers that had been sleeping yesterday" [Our Translation], he personifies the flowers as one beautiful natural element of spring being slept. This sleeping before spring's coming can let the flowers die. Then, the dew covers and blooms them to speak, so the image of flowers shows the pleasant blossom that makes them alive again. Spring is presented in a metaphorical way, this spring dressed itself up clothes from the trees, in which it feels comfortable and enjoyed, exactly like human beings during spring. This enjoyment is obtained from the beauty and the greenness of the land, "And from the trees Spring dressed up itself/ As making an ornamented adornment" [Our Translation]. (Al-Yathi, 1982, P. 92)

Al-Bohtory and Wordsworth portray nature as the source of pleasure and how spring affects the human's mind and soul. Nature is connected to humanity through the presence of the natural soul; that nature's soul is not that different from humanity. Al-Bohtory further emphasizes the same idea by saying "And the breeze became calm then I thought/ It brought the breaths of the beloved gladly" [Our Translation] (Al-Yathi, 1982, P. 92).

Al-Bohtory also depicts spring as the reason to nature to become happy even the flowers. Spring brings the breeze to feel comfortable and pleasant. He shows the breeze as being smelled and breathed by the humans. Similarly, the flowers are personified as a human who breaths and enjoys the beauty that air makes. Similarly, Wordsworth presents the flower's breath as blooming in spring in "Lines Written in Early Spring" poem "And 'tis my faith that every flower/ Enjoys the air it breathes?" (Doren, 1951, P. 78).

The personas in both poems link the words "breaths", "enjoys", "beloved", and "flower" to the human's mood. These words show how people are pleased when they experience the beauty of nature. Closely, the image of spring and the pleasant thought are also depicted by Wordsworth in other poems. In "I Wandered Lonely as a Cloud", the persona 
presents the image of daffodils as pleasant and dancing as he sees them, through the stanzas of the poem. It follows a quatrain-couplet rhyme scheme (ababcc). Each line is written in iambic tetrameter. These daffodils are beside the lake and the trees are fluttering, they look as they are blown by the breeze as Wordsworth portrays:

I wandered lonely as a cloud

That floats on high o'er vales and hills

When all at once I saw a crowd,

A host, of golden daffodils;

Beside the lake, beneath the trees,

Fluttering and dancing in the breeze

(Doren, 1951, P. 494)

In the first line, the persona uses a simile, the speaker is like the cloud that walks everywhere, this cloud observes the beauty of the land, while the greenness of the trees and the blooming plants attracted him. The speaker then personifies the daffodils as dancing for the beauty of nature. These "golden" daffodils are also "fluttering" in the breeze. This image shows metaphorically the mood of the speaker while he wanders as the cloud. Then, the speaker portrays the image of the waves as glinting on the bay; but the daffodils seem more joyful and more pleasant to the speaker than the waves. The amazed and excited speaker also shows the happy mood where the joy cannot be expressed exactly like the perfectness of nature and spring. The metaphor becomes apparently comprehensible as the speaker moves around the area and spreads over mountains, lakes, flowers, and gardens. Another personification is evident here. The dancing daffodils represent a beautiful human image, as they dance in the breeze which might show the speaker's pleasant mood. The speaker also enjoys the image of nature and spring around him in the same poem:

The waves beside them danced; but they

Out-did the sparkling waves in glee:

A poet could not but be gay,

In such a jocund company:

I gazed- and gazed-but little thought

What wealth the show to me had brought

(Doren, 1951, P. 494)

The similar imagery of spring influences both human and nature, and leads to happiness and pleasant thought in the above three poems. The speakers are presented with pleasure, joy, enthusiasm, and freedom. That is what Al-Bohtory also depicts in the following lines in his response to nature and spring. He presents them as the reason to be happy on the speaker's way to Damascus returning from Iraq. He presents his masterpiece as a pleasant speaker who is full of happiness and joy as:

Living in Darya's cold night

Where wine is blended with water from Barada [....]

Damascus has shown its beauty and perfectness

And the promising thing has loyally performed the promise

If you want, you will fill your eyes from

The beautiful town and time which are similar

The clouds spread over the town's districts at night

And the plants in its desert grow numerously

Then you notice wetness

Mellow greenness or twittering birds

As if the summer has passed after its coming

Or spring comes close after a long absence [Our Translation]

(Al-Yathi, 1982, P. 91)

The persona is amazed by the beauty of Damascus, as he returns from Iraq. The cheerful speaker personifies Damascus as the charmful woman who shows her beauty and perfectness during spring. This spring promises the land yearly and loyally it comes to keep it green and happy. The persona mentions some natural subjects of Damascus, he presents spring that makes people, birds, and plants happy. Pleasure is linked to the joyful mood the speaker feels. Moreover, he depicts the clouds that spread around the area and cover the desert as a natural motive to keep the plants and the desert in a pleasant image. The persona is psychologically influenced by the view of spring, so he experiences the beauty of a natural season by creating happiness for people and plants in Damascus. The metaphorical depiction of presenting Damascus as a charming woman who grabbed peoples' eyes and hearts, because of her beauty and faintness during spring as the speaker says in the same poem:

Damascus has shown its beauty and perfectness

And the promising thing has loyally performed the promise

If you want, you will fill your eyes from

The beautiful town and time which are similar [Our

Translation]. ( Al-Yathi, 1982, P. 91) 
Al-Bohtory is known for his love of Syria, so that he depicts this factual context to the reader to enhance the real image of the country. Al-Yathi (1982) recognizes:

When Al-Bohtory recalls Levant, he evokes everything in the

universe that pulses in life and is marked by purity. We see him portrays

through his lines the image of the clouds at the top of the mountains, the

plants appearing in the desert, and the twittering birds fill the life in the

flowed pleasure. As a result, the universe is dewy by rain and Summer goes then the Spring comes. [P. 91. Our Translation]

Al-Yathi claims that Al-Bohtory evokes and presents nature and spring in most of his poems. He relates the speaker's emotions and feelings with nature and soul to depict a pleasant mood to humans, as Wordsworth (1802) states in his preface to Lyrical Ballads that the poet is a "man speaking to men" (P. 6). This man should have a "grater Knowledge of human nature, and more comprehensive soul" (P. 6).

Wordsworth excels in presenting nature as a source of tranquility. Nature is his own world, it is the main theme that Wordsworth presents in his poem "The World Is Too Much With Us; Late And Soon", he complains about the corrupted world, so he says:

The world is too much with us; late and soon

Getting and spending, we lay waste our powers:

Little we see in Nature that is ours;

We have given our hearts away, a sordid boon!

(Doren, 1951, P. 536)

The lines above show the speaker's picturesque image of the material world as different from his own world; he justifies that nature is his real world, and complains from the harshness of people and life. He also criticizes the material world and people with the images of harmful and unharmonious world that keeps the hearts away as "a sordid boon". Wordsworth continues the view of nature as the source of righteousness, purity, peace and strength in the same poem.

For this, for everything, we are out of tune;

It moves us not.- Great God! I'd rather be

A Pagan suckled in a creed outworn;

So might I, standing on this pleasant lea,

Have glimpses that would make me less forlorn;

The persona uses the pronoun "we"; it may show that all humans complain about the real situation of people at the poet's period. The above lines have two exclamations, the first when he says in the same poem "We have given our hearts away, a sordid boon!"

The above exclamation demonstrates a strong emotional movement where the persona asks himself about the reason of the world's ugliness. Furthermore, the persona observes his disgust given that emotion which may be triumph over the reader's link to the corrupt and desperate world. "It moves us not.- Great God! I'd rather be", "A Pagan suckled in a creed outworn;". The speaker eloquently recites another exclamation as he proclaims his priority to admire and recognize nature. Another aspect that can be deeply identified through Wordsworth's poem is the sense of individuality. It makes him to feel alienated and different from other people. Moreover, the thought of the speaker as a romantic man is another aspect that can be deeply identified through Wordsworth's poem. The poem can be suggestive and experimental in tone and form through its broad exclamations and its style that closely resembles natural speech forms. The poem also offers that the speaker may be inspired, having great initiation and a keen understanding of the essence and perfectness of nature, whereas the people around him remain ignorant; trapped within the borders of a corrupt world Nature offers real pleasure and beauty to the people, but people tend to be behind unseen and artificial pleasure and beauty.

Memory and time progression of communion with natural beauty generally are subjects that have importance in Wordsworth's "Lines Composed a Few Miles above Tintern Abbey, on Revisiting the Banks of the Wye during a Tour. July 13, 1798". The poem is a monologue, spoken in imaginative lines by one speaker to himself, indicating to some objects of its imaginary prospect (Emma, 2021, p.1). The language of the whole poem is marked for its power, humility, and good organization. Wordsworth composed it when he had visited the river between Tintern and Monmouth in 1798. The speaker of the poem has two images: the image of the past and the image of the present after visiting the place again. He starts by describing the place through remembering summer and the whole place with the image of the murmuring water as:

Five years have past; five summers, with the length

Of five long winters! And again I hear

These waters, rolling from their mountain-springs

With a soft inland murmur-once again

Do I behold these steep and lofty cliffs,

That on a wild secluded scene impress

Thoughts of more deep seclusion; and connect

The landscape with the quite of the sky 
The day is come when I again repose

Here, under this dark sycamore, and view

These plots of cottage-ground, these orchard-tufts

Which at this season, with their unripe fruits,

Are clad in one green hue, and lose themselves

"Mid groves and copses. Once again I see

These hedge- rows, hardly hedge- rows, little lines

Of sportive wood run wild: these pastoral farms

(Doren, 1951, P. 103)

The persona recites the objects he sees again, and presents their impact on him. The "steep and lofty cliffs," bring to him "thoughts of more deep seclusion". The speaker sees the wreathes of smoke rising up from the chimneys of cottages, and feeling that they may rise from "vagrant dwellers in the houseless woods", or from the cave of a hermit in the forest between the trees. The speaker also shows how his past memory and consciousness of the "beauteous forms" kept in him during his absence (Emma, 2021, p.2). To the speaker's mind, past images of the trees, cottages, and wood show the speaker marvelous sensations, as he feels in the same poem "In hours of weariness, sensations sweet", "Felt in the blood, and felt along the heart;". (Doren, 1951, P.103). The persona shows that all the natural elements from the area, which they look pastoral and simple, keep him calm and tranquil.

Apparently, Al-Bohtory and Wordsworth adopt a descriptive style. They depict a paralleled image of the horse and the foal; each poet describes the horse creatively. Wordsworth presents the foal in an irregular rhyme scheme in his poem "The horse" as:

The foal of generous breed along the plains

Walks stately, balanced on his easy joints,

Round are his hips, his belly short, his neck

Lofty, and sharp his head with muscles swoln;

His breast exults luxuriant, all on fire,

No idle sound appals him of the herd,

(Doren, 1951, P. 488)

Metaphorically, the speaker shows that the foal proudly walks, as if he is striking balance using his steps "Walks stately, balanced on his easy joints". This balanced walk comes from his power and enthusiasm. However, the speaker mentions some major beautiful characteristics of the foal, such as "his lips are round", his "belly is short", his neck is "lofty", and his head is sharp with "sworn muscles". The persona admires the foal's beauty and power. Nothing scares him as Wordsworth says: "No idle sound appals him of the herd" This foal's walk is proud everywhere, the foal attempts and throws himself upon the floods and strange bridges, in which his running is fast and powerful as the speaker depicts in the same poem:

Gave to the winds, and flying, with neighings shrill

Filled all the shaggy round of Pelion high

He hears the din of distant arms, his feet

Chafe, shudder his erected ears, his limbs

Tremble; beneath his nostrils clouds of fire

Forced down, collected, roll in wreaths, his mane

Redundant on his ample shoulder tossed

Floats to the right; strained like a bow, his spine?

Doubles, and unbroken, springing back, he scorns

Al-Bohtory refers to a similar image of the horses with a deep description of its creation, walk, confidence, and power. He describes the horse as a star in the sky, this horse looks so beautiful yet powerful. Admiring the horse pays the speaker to highlight many characteristics to show the horse's power and shapeliness. Al-Bohtory offers a clear image of the horse as he wanders to mention each single feature of the horse. The speaker initiates his poem "The Horse" by "Oh how beautiful the horses in their firstborn are!/ They move like the stars in the darkness" [Our Translation]. (Al-Yathi, 1982, P. 103)

The whole poem shows the beautiful image of the foals and horses, so the persona focuses on different other features of them in the same poem as:

As if someone is genuine in their presentation

As a photographer who enriched their image

They hold crows on their backs with their silky hair

If they are not careful to be familiar to the horses

Then they will cause their death

As if with the rein on their chests,

They are like the tabular ropes in their waking and walking

They compete the wind in its walking

While the sunshine is vanished [Our Translation] 
( Al-Yathi, 1982, P.103)

The speaker shows the images of the arena, the horses, the knights, the trainers of the horses in an accurate depiction. The poet declares that the spiritual relationship between himself and the horse, this relationship is related to the historical and traditional existence with the horses. Like Wordsworth, the poet presents some common characteristics of the horse. He presents the horse with the image of stars which are bright and fascinated. Moreover, the speaker talks about the horse's power and speed in the same poem as:

As if with the rein on their chests

They are like the tabular ropes in their waking and walking

They compete the wind in its walking

While the sunshine is vanished [Our Translation]

(Al-Yathi, 1982, P. 103)

The persona portrays the horse with his rein as a strong fast air, in which the sunshine is blocked, this fast-running blocks even the lights around the speaker. This beautiful scene of the horse attracts the speaker to acknowledge that all watchers admire the way the horse runs. This image of horse, as the speaker presents, attracts even birds to watch the horses running in their arenas.

While they are landing down

Bringing the birds to their nests

In the arena that gets pleased

Where the men become honored [Our Translation]

(Al-Yathi, 1982, P. 103)

Similarly, Al-Bohtory bestows another image of the foal in another poem "The Foal" where the speaker admires how he walks. This love sprung from the psychological and spiritual relationship between the speaker and the foal. This relationship becomes from the horses' and foals' role in wars and invasions. So, we find the speaker explains and appreciates them in his poetical portray. He also returns to the image of how he runs and walks. He says:

As for the foal, we have experienced his day

A day which is enough to talk about his year

He walked with the foals and flew away

Further than their delusions and higher than his

A glad and full of beauty

Coming like the full moon in the sky [Our Translation]

(Al-Yathi, 1982, P. 104)

The persona presents a clear metaphor of depicting the horse as a bird that flies. This fly is shown spiritually rather than physically. This means that this horse is mentally different and physically beautiful. This depiction is attributed to the role that foals and horses play in wars. The reason of describing the foal is to show the poet's pleasure and comfort to be in a battle with the horses. The powerful foal is presented as it precedes the other foals in the field, so his coming is depicted as the full moon that spreads the whole area. Abu- Elhilal Al-Askari states that Al- Bohtory portrays a full image of the beautiful arena with the horses "it seems that the image of the arena is completely depicted in a perfect way, it is the image of a creator who lived in the third century of Hijra, and looked by the lens of the 13th century. He is a photographer who looked, sang, and created. [Our Translation]. (Al-Yathi, P.103).

Wordsworth and Al-Bohtory exhibit a similar description of the cloud as a natural element. In Wordsworth's "I Wandered Lonely as A Cloud", he personifies the cloud as a person who brings pleasure to the daffodils and the land. The persona walks near the hills and valleys while his emotions are lonely and desperate. Suddenly, as he passes a lake, he noticed beautiful yellow daffodils waving in the breeze in front of him.

I wandered lonely as a cloud

That floats on high o'er vales and hills,

When all at once I saw a crowd,

A host, of golden daffodils;

Beside the lake, beneath the trees,

Fluttering and dancing in the breeze.

(Doren, 1951, P. 494)

In the next stanza, waves in the bay were dancing and waving, appearing beautiful at the breeze, but the flowers revolve around the graceful waves in their happiness. So, the persona was gazing "constantly at the flowers and enjoying their beauty" (Maity, 2016, P .3). The word 'gazed' is used twice to refer to how admired or fascinated the persona was. He gazed at "the daffodils for a long time, forgetting other surrounding elements. At that time, he does not think much about the 'wealth' that the flowers had brought to him" (Maity, 2016, P .3). The persona realizes that, may be, after a few days. This 'wealth' is the pleasure and happy memory that he experienced and felt for a long time since the day.

The waves beside them danced; but they

Out-did the sparkling waves in glee:

A poet could not but be gay, 
In such a jocund company:

I gazed - and gazed—but little thought

What wealth the show to me had brought:

(Doren, 1951, P. 494)

The peace of mind, tranquility, and joy which man looks for in life exists in the indulgent and recognized nature. The depiction in which Wordsworth presents in "I wandered lonely as a cloud" This admiration for nature gives peace to the speaker's thinking, even long after his original experiment is over. The features of nature fascinate the speaker because they are dynamic like a painting, but they are vivid with emotion. The persona becomes a glad person with the beautiful natural surroundings around him.

In the 1802 version of the preface to Lyrical Ballads, Wordsworth adds that although his poetic diction was intended to look realistic and simple, he features "a certain colouring of imagination, whereby ordinary things should be presented to the mind in an unusual way" (P. 245). "I Wandered Lonely as a Cloud" is truthful in the way it presents the emotional, imaginative, humble, simple and realistic response to nature.

Similarly, Al-Bohtory depicts a similar image of the cloud. The description of the pleased and rainy cloud is mentioned as the source of happiness to the land. The speaker describes it, as honest and bright natural element, this cloud spreads over all the land:

It is vibrating by the thunder's nostalgia

Its tail is tugged and it promises honestly

It is dropping tears without cause

And its breeze like the flower's

Its ringing is like the lion's roar

And its bright lightening is like Hind's sword

The calm wind has brought it from Najd

And spread out like the necklace's dissipation

Then the land lived comradely

For the beauty of the sprouts in cold

Its water springs in the valleys

As if they are playing beautifully in the cube [Our Translation]

(Al-Yathi, 1982, P. 104)

The diffused cloud spreads over mountains, valleys, and plains. It has a breeze like the flower's breeze, it is bright like the sword. The speaker also presents the cloud as the source of the land's greenness, standing for Spring. Rain from this cloud is shown as the supply of the water springs and growing plants. The persona depicts the cloud in a happy mood, in which the land becomes pleased and joyful. Al-Bohtory is influenced by the image of the cloud and rain as Bassam Seyam (2017) recognizes that "We can identify how Al-Bohtory crystalizes his admiration not only some natural subjects, but in every side which is connected to nature. Al-Bohtory concludes most of his poems by the image of rain, clouds, fountain, sun, and flowers". [P.103. Our Translation]

The persona draws a relationship between the land and the cloud through a personification. The persona personifies the cloud's tears as Al- Bohtory depicts like the heavy rain that helps the trees, plants, and flowers to grow, then the land becomes green and happy "It is dropping tears without cause". This cloud comes after the thunder, and the speaker concludes that the cloud spreads as the necklace's strewing on the land, in which he admires the way of its becoming as strong and rainy. Water springs are also pleased, the speaker concludes in another poem "Its water springs in the valleys/ As if they are playing beautifully in the cube [Our Translation]. (Al-Yathi, 1982, P. 104)

This pleasure is caused by the rain. These water springs are metaphorically depicted as playing in cube, because of the heavy rain from this pleasurable cloud. Al-Yathi (1982) comments on this cloud, as Al-Bohtory "had not left any side of describing its thundered sound, its fragrant breeze, its flashing lightening, and its influence in gardens". [P.94, Our Translation]

The images of rain and cloud are conjoint to Al-Bohtory's admiration of nature. Moreover, the image of the rain is also depicted in another poem "If the Sky does not cry, the land will not laugh with greenness", he says:

If the sky does not cry

The land will not laugh with greenness

And the flowers would never bloom

Unless it gets sick from the heavy rain [Our Translation]

(Al-Yathi, 1982, P. 77)

Based on the metaphor "If the sky does not cry, the land will not laugh with greenness". The speaker explains relationship between the sky and the land. This relationship is connected to rain. He concludes that the rain makes the land happy and green. The speaker personifies the rain from the sky as a weeping woman, whose tears make the land green, standing for fertility "If the sky does not cry". Moreover, the flowers cannot bloom without the sky's rain. The speaker concludes that the flowers and land have a special relationship with the sky. 
This is what Wordsworth also offers in a paralleled image. In his poem "A Spring Morning”, the speaker describes the beauty and goodness of the rain at morning time in spring. The sky rains heavily and the wind blows harder every second all through the night, he shows that the rain makes this morning happy as well as beautiful:

There was a roaring in the wind all night

The rain came heavily and fell in the floods

But now the sun is rising calm and bright

The birds are singing in the distant woods

Over his own sweet voice, the stock dove broods

The jay makes answer as the magpie chatters

And all the air is filled with pleasant noise of waters

(Doren, 1951, P. 56)

The relationship between rain and nature in the above stanza is generally depicted by the metaphor of the pleasant noise. This shows that even the water of the rain causes pleasure, and how this rain makes the floods full of happiness and enjoyment. The personification of depicting the sound of the rain as "sweet voice" is to enhance even the doves of joy. Moreover, the image of being happy because of the rain is also the image of the birds as singing and pleased by the beauty of nature in which the sky was raining at night. The reason of the bright and calm sun is also the rain, so the other image of the sun is caused by the rain that filled all the crops and the land.

The speaker continues the pleasant atmosphere in which the rain caused this happiness, so we find the speaker who shows all things that love sun are out of the doors and enjoy the beautiful and calm atmosphere generally:

"All things that love the sun are out of doors

The sky rejoices in the morning`s birth

The grass is bright with rain drops, on the moors"

(Doren, 1951, P. 56)

The grass is also portrayed as bright, and this brightness comes from the drops of the rain at that night on the moor. The whole picture is to show the concrete relationship between the sky and the land as what Al-Bohtory depicts in his previous poem, so both of the poets glorify the role of the rain and its influence on humans, trees, flowers, grass, crops and the land at the whole in a pleasant and excited image.

Wordsworth and Al-Bohtory are indulged also by the image of nature and the description of the castles. On the other hand, Wordsworth illustrates an image of Peele Castle with different beautiful images of some natural subjects, such as the sea, sun, wind, and water. Natural subjects evoke similar thoughts in each poem they appear in, drawing that Wordsworth has definite personal feelings about those images and what they portray to him. In the "Elegiac Stanzas Suggested by a Picture of Peele Castle in a Storm, Painted by Sir George Beaumont" poem, the speaker presents the whole image as drawn by the poet's friend Sir George Beaumont in a regular rhyme scheme (ABAB). The poem is set on "the death of John Wordsworth, brother of William Wordsworth. However, it depicts how this incident emerged as a catalyst in widening the horizons of Wordsworth in terms of the reality of life and his power of visualization" (Website contributors, 2017, P.1, https://beamingnotes.com/2017/11/13/elegiac-stanzas-analysis-summary-william-wordsworth/).

This poem presents the disappointment of Wordsworth that he had improved in relation to his life that was very optimistic to fit in real life. The persona is influenced by the image of nature through his elegiac stanzas, so he "breathes life into the sea, turning the water into a living creature in this poetic portray" (Website contributors, 2017,P.3). The sea in this poem shows irritation with a sense of tranquility to deliver an atmosphere of beautiful romantic and peaceful picture:

I was thy Neighbour once, thou rugged Pile!

Four summer weeks I dwelt in sight of thee:

I saw thee every day; and all the while

Thy Form was sleeping on a glassy sea.

(Matlak, 1806, P. 4)

The persona calls the castle as "rugged Pile". This alludes to his childhood memories of the Peel Castle. It may be clear that Wordsworth's memories of the place are generally positive and dynamic. He portrays a calm and peaceful atmosphere by creating an environment dominated by beautiful and peaceful natural scenes, with a pure sky and quiet clean air:

So pure the sky, so quiet was the air!

So like, so very like, was day to day!

Whene'er I looked, thy Image still was there;

It trembled, but it never passed away

(Matlak, 1806, P. 4)

After the third stanza, the poem begins to change. In the first part, Wordsworth sets up the thought that the castle is unchanging, "so like, so very like, was day to day", so this change in the poem metaphorically identifies a change in Wordsworth himself, not the castle. 
Wordsworth begins to frame his childhood memories by showing how he represents the image from his memory. Wordsworth connects his innocence and pleasure to sunshine. He paints a brighter look instead of casting it in shadows of a storm and wind.

Ah! then, if mine had been the Painter's hand,

To express what then I saw; and add the gleam,

The light that never was, on sea or land,

The consecration, and the Poet's dream;

(Matlak, 1806, P. 4)

In the end, the persona moves from pleasant memories to the present reality of Wordsworth's life. With his younger brother's death, he concludes that he loses all his innocence, and everything he loves he can never regain and restore. He feels that he can never return to the beautiful memories of his childhood because Beaumont to him is now filled with a "sea in anger", "rueful sky" and "trampling waves".

Then, Beaumont, Friend! who would have been the Friend,

If he had lived, of Him whom I deplore,

This work of thine I blame not, but commend;

This sea in anger, and that dismal shore

$$
\text { [....] }
$$

And this huge Castle, standing here sublime,

I love to see the look with which it braves,

Cased in the unfeeling armour of old time,

The lightning, the fierce wind, the trampling waves

(Matlak, 1806, P. 4)

Finally, Wordsworth shows the sun as a source of happiness and tranquility, the wind is a source of fear and gloom, and the sea is a mystifying creature that appears to have a life of its own. However, the sea and the water were tranquil and castle seemed asleep. The sea then looked to him as the calmest of all beautiful scenes. The main event in the "Elegiac Stanzas" is the death of Wordsworth's brother, which also becomes the reason of his lamentation and the change in the worldview of Wordsworth. He turns to nature as the place where he feels tranquil and hopeful. Nature is his reason to become satisfied after his brother's death. So, he invites himself to live hopefully with "harmony" and "power of joy", which also "Tintern Abbey" poem emphasizes. The poem describes how the speaker should satisfy and keep pleased in harmony with nature:

"While with an eye made quiet by the power

Of harmony, and the deep power of joy

We see into the life of things"

Al-Bohtory offers similar images of nature when he also laments the Caliph's death in the poems "Description of AlMutawakil's Castle" and "Al-Mutawakiliah". He describes the Calipha's castle in Iraq. He further blends nature in his lamentation of the Caliph while he is locally, spiritually, and emotionally close to the Abbasid Caliph. The poet's description of the caliph's residences, their ponds and gardens clearly show his love and deep appreciation towards the Caliph and his sons. Al-Bohtory, as an Arab Bedouin poet recognized that the Abbasid Caliphs were symbols of honor, power, dignity and the Arab Islamic unity. Al-Bohtory's description of the castles is not "a transitory subject for seeking intimacy and living only, but his delicate and accurate description of the residences in detail shows his sublime taste as well" (Al-Hbaiti, 2005, P.156). Al-Bohtory initiates his lamentation towards the caliph (Al-Mutawakel AlaAlah) by describing and relating its beauty to the sea and the wind. The speaker returns to nature to present beautiful images of the castle while he is admired by the natural subjects and focuses on his memory, as Wordsworth presents in his Poem "Elegiac Stanzas Suggested by a Picture of Peele Castle in a Storm, Painted by Sir George Beaumont". The speaker says:

I see your castle domineered with beauty

By the virtue of the castles' givenness to it

Softly, the wind blows and tyrannically follows

A water, and it splits as the seas between its sides

Then the pleasures have been touched and done

And you feel bliss and permanent happiness

Oh, the patron of the dew, the helper

The proponent of the overlie and the best booster [Our Translation]

(Al-Hbaiti, 2005, P. 160)

The persona recognizes that the sea and water are the cause of the beauty of this castle. He concludes that seas can make the castle beautiful and attractive. The speaker mentions the word "happiness" in the sixth line of the stanza above to show the relationship between the sea and pleasure, as the reason of the speaker's tranquility. Wind is also mentioned as another natural subject that fills the castle and lets the water cleave its path and the seas widen in the castle.

Al-Bohtory portrays the image of water and the wind in several poems. He describes Alsabeeh and AlMaleeh castle which the Caliph constructed during Abbasid era in Iraq. He draws the image of the water as: 
A side of the air has become pure and bestows

The water's tenderness in a continuous mood

$$
[\ldots . .]
$$

The wind then continued walking between its sides

Moving without delay or despair [ Our Translation]

(Al-Hbaiti, 2005, P. 104)

He further shows the readers some natural objects used in the construction of this castle. He presents that this water is drifted by the wheels of water and how people move these wheels, in which these people live in bliss and happiness in the castle. The wind moves also between the water wheels and the water fill the castle pleasure and tranquility. AlHbaiti (2005) comments in her study that Al-Bohtory describes this castle in his poems and we must "notice these constructional buildings in these lines. They were adopted as residences of the caliphs that are lofty and bright in their colors. They were as bright stars in the heart of the blackish darkness." [P. 167. Our Translation].

The image of the sky and the image of the constructions built during Al-Mutawakel's era are described in other poems by Al-Bohtory. In "Al-Mutawakiliah, Al-Bohtory presents a real metaphor in describing the whole place. It can be noticed that Al-Bohtory presents the image of Al-Mutawakiliah as high and the castles as bright like the planets in the space. These planets illuminate the darkness of the earth:

I see Al-Mutawakiliah has shown its beauties

As if it has finished its perfectness

The castles are bright like the planets

And they could illuminate the dark for the night walker

It is a livery that is weaved and ornamented

Which has the ranunculus and weaving lavender

If Spring flashes, it is covered

By the morning clouds and the clam wind [Our Translation]

(Al-Hbaiti, 225, P. 169)

The persona admires the way that these castles illuminate the darkness of the paths of the one who walks in the dark places. This metaphor is followed by a new metaphor in the last line of this stanza. The speaker views spring as flashing and covering the land with greenness and joy. After spring spreads over, every subject will be happy and the wind keeps calm and peaceful.

Al-Bohtory, similarly to Wordsworth is fascinated by the images of castles indulged by nature. Nature imparts the two poets a great space to think, imagine, and describe different natural subjects that can lead to a new vision towards life and existence. They are both influenced by the images of spring, horses, clouds, the flowers, castles, water, seas, and rivers as presented in this chapter.

\section{CONCLUSION}

The study invocates the representation of nature in the poems through a thorough analysis, it analyzes and compares the representation of nature emotionally, spiritually and aesthetically. Nature in Wordsworth's main poems represent the idealistic place without any dispute, it is the perfect habitat for peace and pleasure. Wordsworth treats nature as a metaphor to recreate his own passion and happiness, therefore, he wants to build his pleasure through the surrounding images of nature "the pleasure which I have proposed to myself to impart is of a kind very different from that which is supposed by many persons to be the proper object of poetry" (Wordsworth, 1802, p.3).

Wordsworth was influenced by nature and its natural allusions and metaphors. He presents the image of nature as his shelter of tranquility and love where every human being has the right to stay in peaceful coexistence. He also depicts nature as the perfect place of pleasure and peace, he recognizes that man and nature are basically adapted to each other, and that the mind of man is naturally the mirror of nature. He presents nature as the source of the man's pleasure and perfectness. This pleasure comes from the human's interaction with nature in its beautiful images of spring, flowers, clouds and animals. The poet has a realization of God's presence in nature and he got sensuous manifestations that pleasure is in nature. His presentation of nature is perfectly achieved and known among the other romantic poets. In "Tintern Abbey" and The Prelude. For example, Wordsworth has shown to what extent his love of nature is presented through the various images of nature.

Similarly, to Al-Bohtory, nature is the place where he feels peaceful and free, Al-Bohtory emphasizes his Arabic and Bedouin identity through most of his poems. Moreover, the poet takes pride in eulogizing nature and showing it through the elements that show tranquility and quiet serenity, the poet wrote in regular rhyme and rhythm to render emotions as a result of seeing the beauty of nature, therefore, he expresses the deep connection between man and nature.

Al-Bohtory's love of nature was based on his senses. Nature appealed chiefly to his thinking. The poet feels pleasure while he observes the elements of nature, tastes the flavor of nature, smells the fragrance of natural objects and hears the sweet sounds of nature. Al-Bohtory develops a passion for the sensuous beauty of his surrounding nature. The reader feels the beauty of nature when "he/she notices the imaginative poetic images that reflect nature's perfectness, which achieves the reader's pleasure. This pleasure comes from love and peace of nature" (Seyam, 2017, P. 19). [Our Translation] 
Ultimately, Wordsworth and Al-Bohtory admired nature and its perfection. They were capable of getting into the humans' emotions and signified their own feelings with theirs. Their grounds of poetic styles and forms were another aspect of their effort to pierce down through artifice and convention to nature and reality. When they treated nature, they thought of man. Man is the most pleased and wealthy when living in the heart of nature.

\section{REFERENCES}

[1] Al-Basri, A. (1944). The parallelism between abuTammam atae'e and al-Bohtory. Lebanon:The Scientific Library.

[2] Al-Hbaiti, S. (2005). Description of the Residences of the Caliph al - Mutawakel Alalah-in Al-Buhtury's Poetry: The Researches of The Basic Pedagogy, Almusel University Journal, 2(2), 154-190.

[3] Al-Yathi, S. (1982). Al-bohtory among his age critics. Lebanon: Dar Al-Andalus.

[4] Bressler, C. (Ed.). (2015). An introduction to theory and practice. (5 ${ }^{\text {th }}$ ed.).Library of Congress

[5] Doren, M. (1951). The works of William Wordsworth. New York: Random House.

[6] Maity, J. (2016). Daffodils (I wandered lonely as a Cloud) Summary" in Englicist. Retrieved Nov 21 from https://englicist.com/topics/daffodils

[7] Matlak, R. (1806). Elegiac stanzas. England: College of The Holly Cross

[8] Seyam, B. (2017). Sensory configuration in Abbasside nature poetry during the third Hijri century. The Islamic University.

[9] Von Schlegel, Friedrich. (2017). August Wilhelm von Schlegel. Retrieved Jun 9 from https://plato.stanford.edu/entries/schlegelaw/

[10] Website contributors. (2017). Elegiac Stanzas Analysis and Summary by William Wordsworth. Retrieved Nov 13 from https://beamingnotes.com/2017/11/13/elegiac-stanzas-analysis-summary-william-wordsworth/

[11] Wordsworth, William. (2021). Preface to Lyrical Ballads. Retrieved Apr 17 from https://web.english.upenn.edu/ jenglish/Courses/Spring2001/040/preface1802.html

Mohammad Al Matarneh: is a Prof. of English Literature in the Department of English Language and Literature, College of Arts, Tafilah Technical University. He completed his PhD. From UKM Malaysia 2009. He served as a Deputy dean, Head of English Department, Director of Translation and Writing Unit and many other Academic positions. His Research interests: colonial and postcolonial, modern and postmodern literary studies.

Emad A. Abuhammam: currently is a Teacher of English Language in the Ministry of Education-Jordan. He Completed his MA in English Literature from Mutah University - Karak-Jordan/2021, and a Bachelor Degree in English Language and Literature from Tafila Technical University - Tafila-Jordan/2016. Emad is interested in Comparative Literature studies in poetry. 